\title{
4. Cinema Hangs Tough ${ }^{1}$
}

\author{
André Gaudreault and Philippe Marion
}

\begin{abstract}
Starting from a new formulation to the end of cinema issue - "What remains of cinema?" - Gaudreault and Marion answer: "cinema is hanging tough" and argue that the "resilience" of cinema depends on what we are talking about with this word both in terms of digitalization and cultural differences. They examine the different hypotheses arising in this regard from the point of view of the range of words it mobilizes (cinema, movie, moving images, and so on). Differences in naming are "highly significant" as we can observe in a Bogdanovitch-Welles dialogue or at the occasion of the Netflix controversy during the recent Cannes or Venice festivals.
\end{abstract}

Keywords: Digitalization, resilience, Netflix

1 The work on which the present text is based has benefitted from the financial support of the Social Sciences and Humanities Research Council of Canada, the Canada Research Chairs Program and the Fonds de recherche du Québec - Société et culture, through the intermediary of four university research infrastructures led by André Gaudreault under the aegis of the Laboratoire CinéMédias of the Université de Montréal: the Canada Research Chair in Film and Media Studies, the Programme de recherche sur l'archéologie et la généalogie du montage/editing (PRAGM/e), the International Research Partnership on Cinema Techniques and Technologies (TECHNÈS) and the Groupe de recherche sur l'avènement et la formation des institutions cinématographique et scénique (GRAFICS). This article is the English version of a text deriving from a presentation in French entitled "Le cinéma persiste et signe" at the international conference Crise, quelle crise? Cinéma, audiovisuel, nouveaux médias, which took place in Paris in November 2018 at the Maison de la recherche at Université Sorbonne Nouvelle, which included part of a presentation by André Gaudreault, initially in English under the title "The Resilience of 'Cinema'" at the international conference Ends of Cinema at the Center for 21st Century Studies of the University of Wisconsin, Milwaukee (forthcoming in 2020 under the title "The Resilience of the Word 'Cinema' and the Persistence of the Media”), and later in French by videoconference on May 11, 2018 as part of the 5 th International Symposium on Innovation in Interactive Media (SIIMI) organized by the Media Lab of the Universidade Federal de Goiás, in Goiânia, Brazil, under the title "Résilience du mot 'cinéma' et persistance du média."

Chateau, D., and J. Moure. Post-cinema: Cinema in the Post-art Era. Amsterdam: Amsterdam University Press, 2020 DOI 10.5117/9789463727235_CHO4 
What remains of cinema? This is not a new question. It is even a nagging question. ${ }^{2}$ One could very well suggest that it has served as the vanishing point for the entire history of this complex and powerful medium, which also boasts of being an art, the seventh art the French call it. Today there are those who maintain that the upheavals tied to digital technology are changing the state of things more radically than ever before. And yet cinema is hanging tough. Today it may even be going through a period of true resilience. This resilience, in our view, has a special connotation in the French context, in which the word "cinephile" carries a very particular meaning, without parallel in any other cultural space on the planet. There is indeed a quantitative difference between the love for cinema felt by the gentle citizens of France and that found in the 193 other countries in the world. In fact there may very well be a uniquely French way of loving cinema. Questions like these will run through the present text, where they will meet up with, as we shall see, questions of imperialism, hegemony and even fascism ...

The cultural uniqueness of French cinephilia deserves, first of all, to be resituated in the context of a broader uniqueness: that of cinema's place in the "overall audiovisual magma" of the present day. This is the expression used by Stéphane Delorme in the editorial "Pourquoi le cinéma?," found in the March 2018 issue of Cahiers du cinéma to describe the ragout, the Russian salad, the bouillabaisse created in the production of "so-called animated pictures" today. Or rather, should we say, of so-called "animated pictures," an expression so bland, in the end, that we do not know how, in 2010, it managed to rise to the level of being part of the banner of that flagship of French cinema, the $\mathrm{CNC} . .^{3}$

We might ask ourselves, moreover, whether the addition of this impertinent expression, "animated pictures," which here adjoins the word cinema, does not in a sense represent the symbolic death of the latter, of the cinema which never finishes dying, despite in particular the repeated assaults of all the world's Netflixes. These, as we will see below, are much further from the flicks than they make out, just as, as we will also see below, they are far from being as net ("clear" in French - Trans.) as they make out ...

2 It is even the title of a book by Jacques Aumont, 2012: Que reste-t-il du cinéma?

3 France's principal cinema institution, the Centre national de la cinématographie (CNC), changed its name in 2010 (while retaining the same acronym), to become the Centre national du cinéma et des images animées. The adoption of the expression "cinéma et ... images animées" (replacing the more old-fashioned term "cinématographie," little used in French in this way today) shows that this French institution was sensitive to today's tastes and prepared, in order to "modernize" its brand, to downplay the role of cinema in the chorus of media. 
We should note in passing, and this observation is not without interest, that it is not just our dear "CINEMA" which is hanging tough. And which knows resistance, resilience and persistence. There is also the word itself we use in French, "CINÉMA," which lasts and outlasts, beyond the recurring and seemingly imaginary deaths of the medium it describes. It must be said that this French word "CINÉMA" has a tough hide, as tough as the hide of cinema itself. The word has a tough hide and certainly a not particularly discreet charm, if we consider that it is at the root of a strange phenomenon which occurred around 1912 in the English speaking world of this seventh art. We refer to the way this French word "cinéma" was imported into the language of Shakespeare and Faulkner, after the borrowed term was "stripped" of the acute accent overtop the "e."4 And so "cinéma" became "cinema." The strange thing about this story is the way a Gallicism was created to describe the "kinematic thing" in the English-speaking world despite the fact that English speakers already had a quite substantial vocabulary to describe every sort of cinematic activity: movie, film, moving pictures, motion pictures, motography, flicks, etc.

Let's stop here for a moment and consider the imperialistic, fascistic and hegemonic dimensions of the topic introduced so enigmatically at the outset of the present discussion. Here we refer to none other than Roland Barthes! This man, whose death was re-imagined in 2015 as a murder at the center of a "semiological thriller" by Laurent Binet (entitled The Seventh Function of Language, [2015] 2017), had in 1961 denounced what he called "the imperialism [...] of cinema over other visual information technique," as the language of the day would have it. Barthes maintained that this imperialism "could be understood historically," but "could never be justified epistemologically" (1961, 223-225).

If we accept this observation by Barthes, we must acknowledge that things have changed considerably today. The blurring of boundaries which has given rise to what we have called the "gradual digitalization of media" (see Gaudreault and Marion 2015) appears to have had as one of its most forceful consequences that of making cinema lose its lustre and fall from the pedestal atop of which it reigned. For every more or less portable screen of the cruel world in which we live has flattened and placed on the same level the first-run film, the most ordinary television program, the most dazzling music video, the most maladroit amateur film and the most boring home movie.

4 This stripping is not absolutely necessary when a word passes from French to English. Think for example of the term "mise en scène," which preserved its accent (a grave accent over the "e") when it was introduced into English. 
Every screen in the world or, to speak like Guillermo del Toro, all the world's "rectangles" (see Tartaglione 2018), appear to be of equal merit, unless one of them rises above the rest: the oldest of the bunch, the one which reigns over all our dear movie theaters, which today, moreover, screen not just cinema, precisely, now that they have been invaded by the non-film ... ${ }^{5}$

For those who hang tough in loving cinema, we should introduce a little flashback here. Let's go back to the 196os, to the restaurant where Peter Bogdanovich met Orson Welles for a long interview, which has the distinction as well of having burst onto the scene in 2018 (as we will see below):

Peter Bogdanovich: Was it true, Orson, that one director told you not to call them "movies" but "motion pictures?"

Orson Welles: Ah, that was a friend of yours, Peter - that was George Cukor.... Nowadays, I'm afraid the word is rather chic. It's a good English word, though - "movie." How pompous it is to call them "motion pictures." I don't mind "films," though, do you?

P.B.: No, but I don't like "cinema."

O.W.: I know what you mean... In the library of Elèonora Duse's villa in a little town in Veneto, where we've been shooting just now [THE MERCHANT of VENICE], I found an old book - written in 1915 - about how movies are made, and it refers to movie actors as "photoplayers." How about that? Photoplayers! I'm never going to call them anything else. (qtd. in Rosenbaum 1998, 23)

As we can see in this exchange between Welles and Bogdanovich, which took place in Rome, the importing of the word "CINÉMA" by English speakers did not please everyone. In any event the word cinema is flatly rejected by both Bogdanovich and Welles, who mention in turn numerous terms for describing films or cinema: cinema, motion pictures, movies and films, without overlooking indirect reference to another term, a far from insignificant one: photoplay. This word was chosen by the nascent industry among several others through a contest in the trade press in 1910 to find a name capable of giving the greatest degree of respectability to cinema. ${ }^{6}$

5 On the non-film, see Gaudreault and Marion 2015. In French, the expression "contenu alternatif" is also found. There is a greater variety of expressions in English, as Timothée Huerne describes in a recent master's thesis at the Université de Montréal (2017): "alternative content," digital broadcast cinema (D.B.C.), relay, livecasting and cinemacast. As a French translation of the English expression cinemacast, Huerne proposes to speak of ciné-transmission.

6 See the introduction to Grieveson 2004, 1-2. See also a recent article by Louis Pelletier, which remarks: "As we have seen, photoplay and movie both appeared in 1910 in the MHDL data set, 
The rejection of cinema by Welles and Bogdanovich would catch up to the two buddies nearly a half century later, at the time of the clash between the Cannes Film Festival and the video-on-demand platform Netflix in May 2018, as we will see below.

Cinema is thus hanging tough and even, if one will permit us this little play on words, feigning to offer tough love. Tough love: stern support for someone with their long-term welfare in mind, in the present case feigned. For it appears that cinema's various milieux today feel themselves obliged to make a show of demonstrating sympathy or at least a degree of affected, if not cynical interest, in many contemporary practices forming a part of the broad spectrum of present-day activities encompassed by the "cinematic" and the "moving image," in the context of the "great audiovisual magma" typical of our digital age. This is true at one and the same time on the expressive, medium and institutional levels, as well as on the level of what Henry Jenkins has identified as "delivery technologies," establishing, to quote Jean-Marc Larrue $(2015,46)$, "a clear distinction between the media themselves and [...] media content 'delivery technologies"' (Jenkins 2008). ${ }^{7}$ For Jenkins, these delivery technologies are connected to these media or to aspects of some of them, which are placed in the service of kinds of content in order to propagate this content and to make it available, audible, visible, consumable, etc.

This is true, for example, of the new kinds of audiovisual productions now screened in our movie theaters (the non-film, including live broadcasts of operas but also plays, to mention just these two kinds among a boundless choice of live or delayed broadcasts). Such "performances" on movie theater screens are clearly not, strictly speaking, "films" (something that is clear if you consider one of the names used to describe them in French: the horsfilm, or the outside-of-film, precisely), even in cases where they are not transmitted live and must be "inscribed on a support," to talk like one did in the old days, for later projection. Indeed, even though they are screened in a movie theater, that does not make these "non-film" productions a form of "cinema," even if some people are tempted to claim the opposite, based on a number of arguments with respect to the formal qualities of the product which appears on-screen in the end. ${ }^{8}$

but photoplay initially spread more rapidly. Photoplay, however, went into a quick decline after its 1916-17 peak" (2018, 23).

7 This book was published in a French edition in 2013 by Armand Colin under the title La culture de la convergence, where "delivery technologies" is translated as "technologies de fourniture" "supply technologies"), which for us is not as meaningful, at least with respect to our discussion here.

8 These operas, particularly those of the Metropolitan Opera in New York, are always advertised as mere satellite "transmissions" of an on-stage performance in New York, and there is nothing in 
Questions around the delivery technologies of media content will take up a significant part of the present discussion, particularly by viewing them through what we might call the distribution crisis or quarrel (tied up with, among other things, debates around whether films must pass through the "movie theater"). The controversy that has arisen recently between Netflix and the Cannes Film Festival is something like the visible, media tip of this quarrel, echoing the quarrel between dispositifs described by Raymond Bellour (2012). The visible tip, because in a more radical and fundamental sense the submerged part of the iceberg here is the question of yet another identity crisis of the means of expression which is trying to remain cinema. For if cinema is offering feigned tough love, it is also, as an outmoded media institution, widely offered feigned tough love in return by major competitors whose strength and institutionalization were precipitated by the digital. At the same time, this crisis and feigned tough love also raise the question of naming; as we are about to see, these names continue to be highly significant.

\section{The Lessons of Naming}

We must never forget that naming a medium such as cinema is never an inconsequential task, in that it always carries with it the "baggage" of an at least implicit definition of the medium. It is not inconsequential to choose "vues animées," "motion picture" or "moving images." Or even to speak of "film art" instead of "cinematic art." Every "calling card" a medium may present, both synchronically and diachronically, carries with it an undoubtedly teleological and even ideological choice of identity. Recall that Barthes (1977), once again, did not hesitate to denounce language's fascist dimension. By deciding on a name for a medium, we more or less choose to highlight one constituent element among others identified by the institutional authority that has been built up around this medium. It is understood that the identity of a medium is always a homeostasis, a singular yet temporary federation of pre-existing cultural series, as moreover we demonstrated a dozen or so years ago (Gaudreault and Marion 2002, 2006). This is an evolving and at the same time consensual federation, meaning one in tune with the social uses of several cultural series.

the promotional material to indicate that a production crew, headed up by a "putter into images," is at work with a battery of movie cameras, and that what the viewer will see in not a neutral transmission of a scheduled opera. See in particular Gaudreault 2014; see also Gaudreault and Marion 2015. 
To shed some light on the matter, we might digress and look at a remote language, one full of imagery. In Chinese, "comics" are lian huan hua, or "linked images," and "cinema" was at first expressed as xi yang ying $x i$, meaning "Western shadow plays." One also said huo dong ying xi, meaning "moving shadow plays," and dian guang ying xi, or "electric light shadow plays." What won out in the end was a shortened variation of the latter expression, dian ying, or "electric shadows." In other words, while China imported the apparatus and its techniques, it left the device's "baptismal" name (cinématographe, kinetograph, Bioskop, etc.) at the border in order to inscribe "animated pictures" in a properly "local" cultural series: Chinese shadow plays (or, as they are called in China, zhong guo ying xi). Indeed these images were projected onto very familiar screens which until that date had been home to shadows which may have been strongly Chinese, but were not at all electric. This is a screen, or perhaps a "rectangle," in the words of del Toro, which we will discuss below.

It is not just the Chinese, however, who have hesitated when choosing a name for the new apparatus, and it is not just the Chinese also who have come up with names closely linked to pre-existing cultural series. In fact when the French spoke of "vues animées" in the early twentieth century, they too were inscribing cinema in a pre-existing cultural series, that of light shows. The same is true of English, with "animated views." As for the hesitation in Chinese between xiyangying xi, huo dongying, and dian guang ying $x i$, Westerners cannot preach, when you consider that even Orson Welles, as late as the 1960 , was still wondering how best to name cinema! From one point of view, we might say that in the end names have a "crisis engendering" quality: once a name highlights and brings out a parameter of a medium, or gives precedence to one of its constituent cultural series, this works in a sense to frustrate the other elements (or series) not chosen for the medium's name. It also serves to highlight some connotations and not others.

With these preliminary thoughts in mind, let's return to the use of the word "cinema" itself in the English-speaking world. First of all, we must acknowledge that this borrowing consists first of all in that of the lexical unit itself: once imported into the English idiom, the word cinema resembles like a sibling the word from which it was derived, but this is not necessarily true of the meaning the word would come to take on. What is more, from 1912 to 2019 the English word "cinema" followed its own path in the Englishspeaking world, a different path than that of the word cinéma in French. In fact each of these lexical units had, in each language, its own avatars, ups and downs and distortions. This means that we have found ourselves, a 
hundred and some odd years later, in the presence of two almost identical lexical units (differing only by the sharp accent on the "e") in two different languages, but which nevertheless carry with them various connotations which are resolutely specific to each, making communication between the two languages difficult.

\section{Cinema's Distinction (A Very Select Cinema!)}

When we discuss this topic with English-speaking colleagues, it becomes fairly clear that for them the word cinema suggests something more, something bigger, something grander than the word film. Bigger than the word film, used not in the sense of an individual work (as in "a film by Martin Scorsese"), but rather in the sense of cinematic works as a whole (as in the title of the first English-language edition of the Rudolph Arnheim book Film in 1933.This is also true of French, for example in an expression such as "histoire du film français," which one sees from time to time but which is relatively rare compared to "histoire du cinéma français."

The English word cinema, for its part, suggests something which transcends the word film and, it would seem, other terms with the same status: movie, moving pictures, motion picture, flicks, etc. If we accept that the English word cinema carries with it a kind of all-encompassing strangeness for English speakers who prefer film, movies or even motion pictures, we might wonder whether the identity crises which cinéma as an institution is experiencing in the French-speaking world (with all its variations on the level of the medium, its expressive qualities, film production, distribution and consumption, etc.) are not, therefore, experienced less virulently in the English-speaking world.

In fact we might imagine that the English word cinema has a slightly exotic connotation, and even that this might have as a consequence that its canonical rules are taken less seriously, such as that of the supposed necessity of consuming this cultural product in the ceremonial space of the movie theater, called a cinéma in French, with a captive audience. Once English speakers start to use the words film or movie to speak of cinema, we can suppose that this necessarily indicates, unlike the French, a kind of crossover, a degree of transmedial circulation, or a way of recognizing the multiplatform plasticity of the "cinematic," in a sense, or even of legitimizing this.

9 Or in a "festival of films on art," such as the one in Montreal (FIFA). See: https://www.artfifa. com/en. 
What we have just suggested with respect to the varying connotations associated with the way the "kinematic phenomenon" is named in English is perhaps no more than a series of suppositions, and that at a minimum some nuance is required. But recall what Susan Sontag wrote nearly a quarter of a century ago about cinema and cinephilia:

The conditions of paying attention in a domestic space are radically disrespectful of film. [...] To be kidnapped, you have to be in a movie theater, seated in the dark among anonymous strangers. [...] If cinephilia is dead, then movies are dead too. [...] If cinema can be resurrected, it will only be through the birth of a new kind of cine-love. (1996, n.p.)

It is interesting to note that Sontag passes from film ("disrespectful of film") to movies ("then movies are dead too") to cinema ("if cinema can be resurrected"): cinema, then, seems to be a kind of final stage in Sontag's argument, its high point, as if the privileged future of film will have to be carried out through the cinema of cinephilia. By associating it in this way with the happy few, with the cinephiles - if we take Sontag's thoughts where they lead us - the word cinema appears at first sight to have little compatibility with the flexibility and transmedial tolerance we just mentioned, in tune with the flexibility of the names (movies, motion pictures, etc.) found in the English-speaking world. But a closer look shows that this may only be a seemingly opposite meaning. For we could follow through on our thinking and consider that, given the cultural pragmatism which characterizes them, English speakers (perhaps we should say instead "Americans?") accept both sides of the "cinema" phenomenon:

- $\quad$ on the one hand, there is the expressive principle of filmic images and moving pictures, which can be distributed and consumed in multiple ways and by means of a variety of delivery technologies. And this is further amplified by the great plasticity of the digital. We could add that here again we find the concrete prosaic side of English speakers: does the expression "moving images" evoke something like "getting your hands dirty" as a way of refuting the elitist and sense of the word cinema, looking down from on high?

- $\quad$ on the other hand, precisely, and on the other side of the bundle of media that is cinema, there is the "cinema of distinction," whose definition is more restrictive and more elitist, in keeping with the highly debated canonical definition of cinema in the French-speaking world (and the source of the controversy at the Cannes Film Festival in particular) as a screening in a movie theater for an audience both captive and passive. 
If we are concerned with the former - moving images and the filmic - movie theaters would be just one possible application for viewing a film. But if we put ourselves in the shoes of the defenders of the "cinema" position, more restrictive conditions apply, similar to those of the canonical cinema system. Depending on whether one is in camp A or camp B, the idea of crisis is considerably different. In camp A, everything is fine and dandy and the cinema is gaining ground, as Philippe Dubois argues (Biserna, Dubois, and Monvoisin 2010). In camp B, on the other hand, there are plenty of reasons to be worried... As we shall see, this tension strangely resembles that more or less implicitly behind the crisis pitting Netflix and Cannes against each other.

\section{Orson and His Posthumous Misadventures}

Creating a Gallicism to describe the "kinematic thing" was thus not always unanimously endorsed, as seen in the exchange between Orson Welles and Peter Bogdanovich. Each of these figures was in the headlines in 2018 because of an immense brou-ha-ha that occurred in the heart of the "cinema" industry. We refer to the unfortunate event at the Cannes Film Festival, where Netflix hurriedly withdrew Welles's final film, THE OTHER SIDE OF THE WIND, which had never been completed before being finished by the good graces of Bogdanovich himself (thanks moreover to coin from Netflix ...). The film was supposed to launch at Cannes in a world premiere. What Welles and Bogdanovich were subjected to was thus a true outrage. They were the collateral victims of this war between two conceptions of what cinema should henceforth be: a new, multiplatform conception, according to which watching a film in a movie theater is, in the end, only one way among others of seeing it (a cinema app), in a sense; and a more "traditional" conception, according to which multiplatform viewing is accepted, yes, as long as the movie-theater presentation is preserved, protected, privileged, etc.

This war ${ }^{10}$ recently brought into conflict champions of each of these camps: in the left corner, Netflix (represented here by Ted Sarandos, chief content officer for the famous round-the-clock broadcasting platform), and in the right corner, the no less famous Cannes Film Festival (represented here by Thierry Frémaux, the delegate general of the festival, which is said to

10 And it is a real war, if we are to believe the journalists who are constantly using the metaphor. See in particular: https://www.challenges.fr/cinema/ pourquoi-la-guerre-est-declaree-entre-netflix-et-le-festival-de-cannes_580389. 
receive more media coverage than any other film festival in the world $\left.{ }^{11}\right)$. In this war with Cannes, Netflix decided, for the May 2018 edition of the festival, to boycott the event because of its decision to exclude from competition any film not intended to be distributed to movie theaters. Netflix thus packed up its marbles and went home, withdrawing all its films from Cannes, even those being shown outside competition: "The festival has chosen to celebrate distribution rather than the art of cinema," declared Sarandos, who said that he was thinking of "the future," while Cannes, he claimed, was "stuck in film history."12 You would think the world had been turned upside down, with Netflix, through Sarandos, championing cinematic art and creation. Netflix, the king of continuous streaming and multiplatform circulation. It is such a powerful force that some commentators have not hesitated to brandish the symbolic date of a new era in film history: "ANN," for Ante Netflix Natum ...

But is it truly cinema history which is in question here? We should write instead "in the history of moving images," or of "images in movement" ... In order to avoid saying too bluntly that Netflix is still cinema. And yet ... who knows if streaming platforms will not soon be seen as one of the last refuges of cinema itself? Perhaps public opinion will think this. In any event, one must not forget the words of Christian Metz, who demonstrated quite well that it is not our prerogative to decide what is and what is not cinema: "cinema is nothing more than the combination of messages which society calls 'cinematic' - or which it calls 'films'” ([1971] 1974, 26).

\section{Netflix, or the Paradoxical Memory of "Flicks"}

In this sense, going back to the "naming" question confirms this idea of a topsy-turvy world. And, while we're at it, let's look at the label "Netflix" itself. The name of this California-based firm seems to us to fit perfectly with our argument. Netflix is a kind of portmanteau word in which we see, on the one hand, a direct reference to the "Net," without which the company would surely not be what it is, and on the other hand the word "flix," at first glance more unexpected. As mentioned above, flicks (or flickers) is a

11 It should be noted that Frémaux is also president of the Frères Lumière association and director of the Institut Lumière in Lyon, which will be important to our remarks below.

12 See https://www.vanityfair.com/hollywood/2018/04/netflix-not-going-to-cannes-tedsarandos and https://newsbeezer.com/portugaleng/netflix-arguments-and-feminist-pressuresset-the-tone-for-the-cannes-film-festival-07-05-2018-illustrated/. 
term used to describe the film medium. The term is metonymic, because it refers to a singular quality of projecting images on film: the flickering or blinking of the image, or if one prefers the traces left by the instability of the image, whose luminosity periodically wavers - a little like television, in fact. Reading Lillian Gish's memoirs, we learn that the word "flickers" was in use in the early 1910s. The actress reports that D.W. Griffith threw a fit when one of his actresses or extras said, without a second thought, that she was working in the "flickers": "Never let me hear that word again in this studio," Griffith is said to have remarked, continuing:

Just remember, you're no longer working in some second-rate theatrical company. What we do here today will be seen tomorrow by people all over America - people all over the world! Just remember that the next time you go before the camera. $(1969,76)$

We must not forget that the word flickers carries with it, in the view of some, a whiff of scorn for cinema, that "entertainment for serfs." Flickering was seen as a defect, an imperfection of the moving image, or if one prefers a noise in the communication. We know that in communication theory, however, while noise is everything that impedes communication, it is also what enables artistic expression. Without noise there is no art! This is what happens with cinephilia, but it is also what happens in the world of silver gelatin purists, who resist the supposedly clinical and sterile smoothing out of the digital, with its legendary coldness. This, moreover, is the view of someone such as the American filmmaker Babette Mangolte, who rails that "the lack of a shutter is what lies at the heart of the difference between the digital and silver gelatin film stock. No more flicker. No more heartbeat" (2004, 419).

For Mangolte, then, the "noise" of flicker lies at the heart of the movement generated by the images filing past. This is the filmic's living palpitation. Mangolte does not hesitate, moreover, to compare flicker to a heartbeat. For her, the "interference" of flickering is in a sense the very symbol of resistance to the digital. As we can see, the connotations of the word flick are loaded, and similar to the distinction we mentioned above with respect to the Gallicism cinema. By bringing together these two semes with such different connotations (the seme "net" refers to the digital, and the seme "flix," rather, is a reference to human palpitation, to cinematic art and distinction), Netflix appears to want to indicate a vocation, a mission: that of being capable of doing the splits and championing cinematic excellence by using the digital as a springboard and megaphone. 
A quick glance at the company's first logo (1998-2000) confirms this interpretation. ${ }^{13}$ There we see an old piece of film unspooling from between the words "net" and "flix," naming the firm. We know the extent to which celluloid, almost as much as the movie theater screening, was for a long time a powerful ingredient of canonical cinema. This "mission" (to establish itself as the agent of the living filmic on the Net, to be the "strong arm" of the digitized filmic), which to our mind is seen in the name Netflix, is a good match with Sarandos's triumphant remarks, which hold that "film art" is now in the hands of Netflix. The paradoxical and vaunted identity of the Netflix paradox has also been confirmed more than once by film critics: "Netflix is the savior of highbrow cinema," reads the headline of an article by Lorenzo Codelli about the Venice film festival. In this article he quotes from a letter by Gilles Jacobs dating from the start of the event in Venice. He means that authors have no need of movie-theater distribution or of the canonical definition of cinema in order to hang tough as fully fledged authors. Even better, looking back we can agree with Natalia Aspesi, who writes that "with streaming, Fellini's last film would have found the money." In this respect, the conclusion of Codelli's article appears to us to be especially edifying:

The complete freedom that Welles, Cuarón and the Coen brothers had, who can give you that today? Not only in terms of money. I refer to the kind of creative freedom which intoxicated Welles in Hollywood at first. Freedom from the worry of being dared to rid oneself of all pre-established rules. Neither Cuarón nor the Coen brothers, nor the winners of an Oscar or a Palme d'Or, would succeed in the classical cinema milieu. That Netflix has made distribution immaterial to the all-powerful may appear to be a paradoxical farce of destiny. I don't envy filmmakers, film festival directors or movie-goers in rickety traditional movie theatres, in Italy or elsewhere. Scattered, shocked, unnerved, disconcerted at what's happening. And it is happening, hoo boy, at the speed at which, in the masterpiece by the Coens, the singing cowboy Buster Scruggs (Tim Blake Nelson [in THE BALlad OF BUSTER SCRUGgs]) goes to heaven! $(2018,10)$

In response to Frémaux - whom Codelli nicknames Scaramouche after the Cannes crisis - Guillermo del Toro, president of the 2018 Venice Film

13 The two logos in question can be found at: https://me.me/i/net-flix-com-first-logo-usedfrom-1997-to-20oo-netflix-831f23c1395642a7893bcfa43bo51829. 
Festival jury and a filmmaker not necessarily beholden to Netflix, insisted on returning to the fundamentals of the content and know-how of filmmaking:

I think that films are judged by what exists in that rectangle. Everything else that exists outside we can discuss and have an opinion on. But the quality of filmmaking and storytelling is what we will occupy ourselves with; it's only in that rectangle that we allow life to exist in cinema. (See Tartaglione 2018)

This argument in favor of a kind of cinematic know-how is undoubtedly tied up with the "getting your hands dirty" aspect which, in our view, characterizes the English-language film vocabulary. At the same time, by advocating a return to the content of the rectangle (and not to that of screens, which for him is perhaps a term with too many connotations), del Toro may have been wanting to confirm the spirit of Netflix: the interface and delivery terminal are not important. What counts is what happens on the screen interface (whatever that screen may be).

Here we find the idea we have developed about the "who cares" cinema crowd: it does not matter how one defines this media machine, as long as it produces interesting film stories. Del Toro insists, moreover, on the continuity he believes is being carried out by Netflix: "Netflix is not the end of cinema, it's the continuation of a process that began a century ago." 14

One thing is certain, and that is that the "cinema" industry is in tumult, and the advent of the digital is still producing gigantic shock waves, even in the field of cinema studies. Think, for example, of the fully justified complaint by some people in the field, including Jacques Aumont, who here points out an unfortunate linguistic void:

What we lack in the end, to put this relatively simple situation simply [he is referring to the fact that cinema is no longer the only form of moving images], is a word - a single word which would say "diverse social uses of moving images." (2012, 59-60)

In fact the French word cinéma refers to only one of the "social uses" of the above-named moving images (which include television, video, holography, the Internet, opera transmissions in so-called movie theaters, museum

14 Quoted by the France-Presse news agency. See: https://ici.radio-canada.ca/nouvelle/1122683/ mostra-venise-alfonso-cuaron-recoit-lion-or-film-roma. 
installations, performances with projection, etc.). In any event, the French word cinéma is more evocative, more appealing and much more glamorous than the expression images en mouvement. We might even say that it has a touch of poetry and brings with it a hint of enchantment and mystery. This is even truer, it appears to us, for English speakers who employ the Gallicism cinema, a highly abstract and evocative term, whose status as a word from a borrowed language is keenly felt. In any event, it is clear that this glamorous element of the French word cinéma is at the root of its importation and implantation in the English language in the 1910 s.

\section{Translated by Timothy Barnard}

\section{References and Further Reading}

Aumont, Jacques. 2012. Que reste-t-il du cinéma? Paris: Vrin.

Barthes, Roland. 1961. "Première conférence internationale sur l'information visuelle (Milan, 9-12 juillet 1961)." Communications 1: 223-225. http://www.persee.fr/web/ revues/home/prescript/article/comm_0588-8018_1961_num_1_1_938.

—. 1977. "Language ... Is Quite Simply: Fascist." Inaugural lesson as the Chair of Literary Semiology at the Collège de France, January 7. http://egophelia.free. $\mathrm{fr} /$ pouvoir/barthes.htm.

Bellour, Raymond. 2012. La querelle des dispositifs. Cinéma - installations, expositions. Paris: P.O.L.

Binet, Laurent. (2015) 2017. The Seventh Function of Language. Translated by Sam Taylor. New York: Farrar, Straus and Giroux.

Biserna, Elena, Philippe Dubois, and Frédéric Monvoisin, eds. 2010. Extended Cinema/Le Cinéma gagne du terrain. Pasian di Prato: Campanotto Editore.

Bogdanovich, Peter, and Orson Welles. 1998. This Is Orson Welles. Edited by Jonathan Rosenbaum. New York: Da Capo.

Codelli, Lorenzo. 2018. “'Netflix le sauveur du cinéma d'hauteur!': Cannes - Venezia revolution." Cinemazero Notizie 38, no. 9 (October).

Delorme, Stéphane. 2018. “Pourquoi le cinéma?” Cahiers du cinéma, no. 742 (March). Gaudreault, André. 2014. "Quand la captation opératique se fait son cinéma. Du relatif anonymat des 'enregistreurs d'opéras' à l'ère de l'agora-télé." In Musique et Enregistrement, edited by Pierre-Henry Frangne and Hervé Lacombe. Rennes: Presses universitaires de Rennes.

—. 2019. "Résilience du mot 'cinéma' et persistance du média." Anais do V Simpósio Internacional de Inovação em Mídias Interativas. https://siimi.medialab.ufg.br/ up/777/o/Andre-Gaudreault.pdf. 
- 2020. "The Resilience of the Word 'Cinema' and the Persistence of the Media." In Ends of Cinema, edited by Richard Grusin and Jocelyn Szczepaniak-Gillece. Minneapolis: University of Minnesota Press.

Gaudreault, André, and Philippe Marion. 2002. "The Cinema as a Model for the Genealogy of Media." Convergence: The International Journal of Research into New Media Technologies 8, no. 4 (Winter): 12-18.

- 2006. "Cinéma et généalogie des médias." Médiamorphoses 16 (April): 24-30.

- 2015. The End of Cinema? A Medium in Crisis in the Digital Age. New York: Columbia University Press.

Gish, Lillian, and Ann Pinchot. 1969. Lillian Gish: The Movies, Mr. Griffith, and Me. Englewood Cliffs, NJ: Prentice-Hall.

Grieveson, Lee. 2004. Policing Cinema: Movies and Censorship in Early-TwentiethCentury America. Berkeley: University of California Press.

Huerne, Timothée. 2017. Vers une théorisation du hors-film: Le cas spécifique de la ciné-transmission. Master's thesis, Université de Montréal.

Jenkins, Henry. 2008. Convergence Culture: Where Old and New Media Collide. New York: New York University Press.

- 2013. La culture de la convergence: Des médias au transmédia. Translated by C. Jaquet. Paris: Armand Colin.

Larrue, Jean-Marc. 2015. "Du média à la médiation: Les trente ans de la pensée intermédiale et la résistance théâtrale." In Théâtre et intermédialité, edited by Jean-Marc Larrue, 27-57. Villeneuve-d'Ascq: Presses universitaires du Septentrion.

Mangolte, Babette. 2004. "Une histoire de temps: Analogique contre numérique, l'éternelle question du changement de technologie et de ses implications sur l'odyssée d'un réalisateur expérimental." Trafic 50 (Summer).

Metz, Christian. (1971) 1974. Language and Cinema. Translated by Donna Jean Umiker-Sebeok. The Hague: Mouton.

Pelletier, Louis. 2018. "From Photoplays to Movies: A Distant Reading of Cinema's Eventual Legitimation from Below." Film History 30, no. 2.

Rosenbaum, Jonathan, ed. 1998. This Is Orson Welles. New York: Da Capo.

Sontag, Susan. 1996. "The Decay of Cinema." New York Times, February 25, 1996.

Tartaglione, Nancy. 2018. "Guillermo Del Toro on Gender Equality: 'It's Beyond a Gesture, It's a Need' - Venice.” Deadline, August 29, 2018. https://deadline. com/2018/o8/guillermo-del-toro-gender-equality-netflix-venice-film-festival-1202453975/. 


\section{About the Authors}

André Gaudreault is Professor in the Department of Art History and Film Studies at the Université de Montréal and Canada Research Chair in Film and Media Studies. He is director of TECHNÈS (the International Research Partnership on Film Techniques and Technologies), GRAFIM (the Groupe de recherche sur l'avènement et la formation des identités médiatiques), and OCQ (the Observatoire du cinéma au Québec). A specialist in early cinema and a pioneer in film narratology, his current research focuses on the advent of editing, the phenomenon of opera retransmission in movie theaters, technological innovations from an "archaeological" perspective, and the impact of digital technology on the media universe. His publications include, Du littéraire au filmique. Système du récit (1988), Cinéma et Attraction. Pour une nouvelle histoire du cinématographe (2008), La fin du cinéma? Un média en crise à l'ère du numérique (with Philippe Marion 2013), and Le récit cinématographique. Films et séries télévisées (with François Jost 1990, 2017).

Philippe Marion is Professor in the Department of Communication at the Catholic University of Louvain (UCL). Co-founder of the Observatoire du récit médiatique $(\mathrm{ORM})$ and the Interdisciplinary Research Group on Cultures and Arts in Motion (GIRCAM), he is also director of the Media Analysis in-depth research unit at UCL and administrator of the Collectiana Foundation. Visiting professor at the University of Paris Sorbonne and the University of Neuchâtel, he has been principal investigator for the EOS (Excellence of Science) research program since 2018. Specialized in media narratology and visual culture, his books include, Schuiten, Filiation (2009) and La fin du cinéma? Un média en crise à l'ère du numérique (with André Gaudreault 2013). As a pianist and composer, he participates in numerous film festivals (including the Crazy Cinematograph project). 
